\title{
Science Education in Post-Truth Age: Metaphysical Reflections from Bruno Latour's Science Studies
}

\author{
Nathan Willig Lima ${ }^{\circledR}$ Brazil \\ Pedro Antônio Viana Vazata ${ }^{\circledR}$ Brazil \\ Fernanda Ostermann ${ }^{(0)}$ Brazil \\ Claudio José de Holanda Cavalcanti ${ }^{\circledR}$ Brazil \\ Andreia Guerra de Moraes ${ }^{\circledR}$ Brazil
}

The term post truth was chosen as the word of the year by the Oxford dictionary in 2016 . Today we see the proliferation of the term fake news as well as the dissemination of alternative views to science, such as "flat Earth", integrative therapies, and anthropogenic global warming denial. Usually, postmodernism is blamed for subsidizing such movements theoretically. In the present article, we defend the thesis that both, the official discourse of science (modernist discourse) and its main criticisms (including postmodernism) seem to be propositions that sustain the contemporary scenarios of production and proliferation of post-truths. From Bruno Latour's Science Studies, we reflect on the metaphysical basis of such perspectives and present an explanation to the formation of the "post-truth" through two different mechanisms, i.e, the presentation of a reduced vision of nature of science and the erasure of the network that sustains scientific propositions. We also defend that Science Education can adopt an alternative metaphysical basis, developed by Latour and collaborators in dialogue with different philosophical and sociological currents, contributing to the formation of citizens able to have a critical position in the contemporary socioscientific scenario.

Keywords: Post-Truth; Metaphysics; Science Studies; STS; Latour.

\section{Introduction}

The end of the nineteenth century and the beginning of the twentieth century are marked by the rise of scientism in modern society and of positivist philosophy in science. In the discourse of demarcation and epistemological signification, the hegemony of empiricism was revisited, as in the Tractatus by Wittgenstein (1968) and in the studies of the Vienna Circle (Goldstein, 2008). In addition, the belief in scientific rationality motivated the conception of a modern, civilized and scientific man in opposition to an irrational, mythical, uncivilized past. Such a view of the superiority of science as compared to other forms of knowledge, supported by empiricist or rationalist assumptions - as in Popper's (2008) epistemology - also promoted the formation of science conceptions typical of modern discourse, attributing characteristics as neutrality and linearity to it (Deconto, 2014), besides promoting a salvationist vision of humanity 
(Auler \& Delizoicov, 2001).

However, from the fifties of the twentieth century, the euphoria regarding the scientific ideal was gradually slowed down in favor of a feeling of disbelief and demotivation in relation not only to science, but also to humanity - marking the beginning of a postmodernist period (Lopes, 2013). The impacts of the World War II, including the advance of nuclear science and its innate miscegenation with geopolitical interests (Deconto, 2014), as well as environmental studies (Carson, 1994), have enabled the creation of a context in which the scientific ideal (and the myths attached to it) could be placed under suspicion. In the field of History and Philosophy of Science, specifically, the proposition of non-absolutist views, as defended in The Structure of Scientific Revolutions (Kuhn, 1996), exemplifies precisely the emergence of the possibility of thinking about science outside the ontological and epistemological objectivism inherited from modernity, allowing the reflection on science in its relations with society and with culture. Such movements have paved the path to question the privileged place occupied by the scientific discourse, promoting the emergence of alternative visions.

Despite the benefits that can come from the opposition to the hegemonic and colonialist discourse of science (Santos, \& Meneses, 2009), the movements of relativization of knowledge and truth produced unexpected side effects. In 2016, the Oxford Dictionary chose the word post-truth as the word of the year, "denoting circumstances in which objective facts are less influential in shaping public opinion than appeals to emotion and personal belief" (Oxford Dictionary, 2016). Today, in the same perspective, we see the increasing use of the term fake news in social networks (Idoeta, 2018). Furthermore, it is clear the adoption and dissemination of alternative perspectives to the scientific ones, such as the flat Earth model (Alvim, 2017), the defense of alternative therapies (Lima \& Nascimento, 2018), the negation of the effect of the vaccines (Corrêa, 2014) and the denial of the anthropogenic global warming (Junges, \& Massoni, 2018). Such visions hinder public opinion on issues that have not only intellectual relevance, but which concretely impact the future of our society. Scientific and technological development has hybridized humanity with the rest of the planet in such a way that what is built on nature affects the ways of society and what is disputed in society affects the way of nature. In this way, the post-truth discussion is also a discussion of the future of our existence and survival in the Anthropocene period (Arènes, Latour, \& Gaillardet, 2018; Latour, 2014; Latour, \& Lenton, 2018).

Contemporary thinkers blame postmodern thinking for providing theoretical support for the formation of post-truths (Mcintyre, 2018). However, in the present article, we have preferred an alternative path and defend the thesis that both the (modern) scientific discourse and the main criticisms of it (including postmodernism) have metaphysical bases that are responsible for fostering the production and proliferation of "post-truth scenarios". We propose that the way in which the reality is presented by all these discourses makes public opinion confused in the middle of sociotechnical controversies through two distinct mechanisms, namely, the presentation of a reduced 
view of the nature of science and the erasure of the network that sustains scientific propositions.

To structure this thesis, we discuss the metaphysical bases of the discourse of modern science as well as some of its main criticisms according to Bruno Latour's Science Studies. In the sequence, we present an alternative metaphysical view, developed and articulated by Latour and collaborators in their Science Studies in dialogue with the Monadology and Sociology by Gabriel Tarde (2007), the Symmetrical Sociology by Michel Callon (1984) and the Theory of Propositions by Alfred Whitehead (1978). From such philosophical reflections, we redefine the concept of post-truth and, opposing the concept of the Oxford Dictionary, present an explanation of how both the adoption of scientific visions and other criticisms corroborates the spread of post-truths. Finally, we discuss some possibilities that can be taken into account in order to develop a Science Education with an alternative metaphysical basis (in line with the view of Latour and his collaborators) - which falls neither in the absolutist nor in the relativistic views by the others perspectives and which can be a way of contributing to the public debate on the conflict between scientific visions and alternatives to science.

\section{Reflections on Metaphysics and Science}

In Pandora's Hope, Latour (2017) points out that he believes in "reality" when he responds to questions from a psychologist ${ }^{1}$. In his reply, the French philosopher further adds that we know more today than we have known in the past, and that science is cumulative $^{2}$, a view that is completely antagonistic to what is usually related to Latour (Slezak, 1994). How can one of the greatest critics of science and perhaps one of the great contributors to weakening its credibility (Latour, 2004b) advocate such a "conservative" stance?

To explain his answers, Latour indicates the path to be followed: "Do we really need to swallow these unsavory pellets of textbook philosophy to understand the psychologist's question? I am afraid so, because otherwise the innovations of science studies will remain invisible" (Latour, 2017, p.19). In the same way that Science Studies cannot be understood without analyzing their metaphysical bases, it is not possible to understand the post-truth problem without referring to the ontological view that supports it. To discuss this issue, we will present some reflections of Latour on the metaphysical bases of science and some of the critiques of the scientific discourse.

\section{The Official Speech of Science}

Latour (1999) indicates the proposition of mind-body duality made by René Descartes as one of the inaugural landmarks of the discourse of modern science. More specifically, Latour discusses Descartes's attempt to explain from such duality "how an

1 Some strands of postmodernism consider that reality is an effect of discourse. Such a question directed to Latour is probably due to being confused as a postmodern scholar (Lima, Ostermann, \& Cavalcanti, 2018a).

2 The idea that science advances cumulatively is questioned at least since the Thomas Kuhn's (1996) work. 
isolated mind could be absolutely, not relatively, secure from an object of the outside world" (Latour, 2017, p.16). Such a separation between an inner mind and an external material world, which gives rise to what some authors call the paradigm of mindbody duality (Searle, 2004), generates, according to Latour, the following question: how is it possible to guarantee the existence of the world and the reliability of what we perceive? The famous phrase of Descartes cogito ergo sum (I think, therefore I am) indicates that the guarantee of the existence of the mind is provided by the existence of thought. On the other hand, the guarantee of the existence of the outside world, in the Cartesian argument, demands the existence of God (Latour, 1999b; Searle, 2004). In this conception, what characterizes our humanity is in the non-material mind, since matter is totally inert.

The consolidation of the subject-nature dichotomy occurs, according to Latour (1999b, 2013), in the Enlightenment period, mainly within the philosophical construction of Immanuel Kant, according to which "objects-in-themselves" are inaccessible to the "transcendental ego" (Kant, 2005). In Kantian philosophy, the encounter between beings and objectsisonly possiblethrough an intermediary-thephenomenon. In this proposition, we are enclosed in our own cognitions, whose validity is only guaranteed by an $a$ priori ${ }^{3}$ judgment (Latour, 1999b). The validity of knowledge is therefore given by the validity of such absolute and universal judgments ${ }^{4}$, constructs proper to the mind apart from matter. Starting from such a view, Kant defines enlightenment as the ability to think for itself: "The motto of enlightenment is therefore: Sapere aude! [Dare to be wise!] Have the courage to use your own understanding!"(Kant, 2009, p. 6). Such a description of intellectual development reinforces the notion of his philosophy that the construction of knowledge takes place "in the subject" internally5. In his opus magnum, Kant (2005) uses his metaphysics to justify and validate scientific knowledge. In summary, the metaphysical description that supports modern science, the separation between nature and society, can be represented in the scheme of Figure 1.

3 Kantian thought is so strong in the structure of Western philosophy that it even defines its subareas. Since objects-in-themselves exist independently and are inaccessible to the transcendental ego (except through the intermediation of the phenomenon), two areas differ: the first, ontology, is the study of beings-in-themselves; and the second, epistemology, is the study of knowledge (Pessoa Jr., 2009).

4 Kant (2005) defines two criteria for the recognition of an a priori judgment: it must be absolute and universal. As examples, the author brings the notion of causality, Euclidean geometry, space and time - concepts whose universality were placed under suspicion in Modern Physics. Such insight made Einstein, for example, claim that it is impossible to propose final categories as Kant supposed (Einstein, 2006). For a discussion of Einstein's philosophical thinking about Kant, we suggest the work of Dahmen (2006).

5 The focus of the cognitive process on the subject, proposed by Kant, directly influences Education and Science Education through cognitivist theories such as Jean Piaget's (Fabricius, 1983; Otte, 1998) and David Ausubel's (Valadares, 2011). In addition, in the literature, articles that discuss Kant's ideas can be found in the Teaching field (Lang, 2002). 


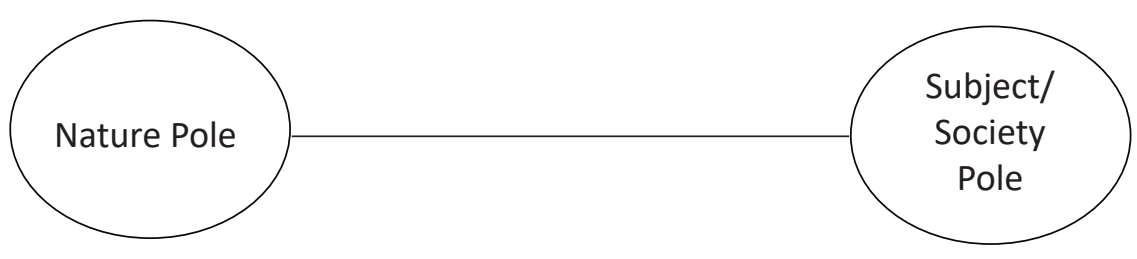

Figure 1. Adapted from (Latour, 1992). On one side there is the subject, cloistered within himself, and the subjects between them $\left(\right.$ societ $\left.^{6}\right)$. On the other side, there is nature, the field of objects-in-themselves. Both ontological poles are irreversibly apart from each other.

The split between nature and society implied several other divisions in the modern world, such as the aforementioned distinction between ontology (objectin-itself study) and epistemology (study of knowledge), as well as the differentiation between epistemology and politics (the study of the relation of men among themselves). These new divisions represent nature as apolitical and bring the following problem: how can Science talk about the world of nature without using the notion of God as Descartes or the absolute judgments as Kant? The ontological abyss that separates the world-initself (nature) from the symbolic representations (belonging to the social "world" of language) has created an epistemological problem. Modern science, even though much it takes to reach the object-in-itself, is cloistered within the world of language. The modern solution to this dilemma was to propose that the falsity of a scientific sentence can be verified by a test of correspondence with the world's entities - as in Tarski's Theory of Truth (Popper, 2008). This modern ontological-epistemological approach proposed by the Moderns can be represented by the diagram of Figure 2.

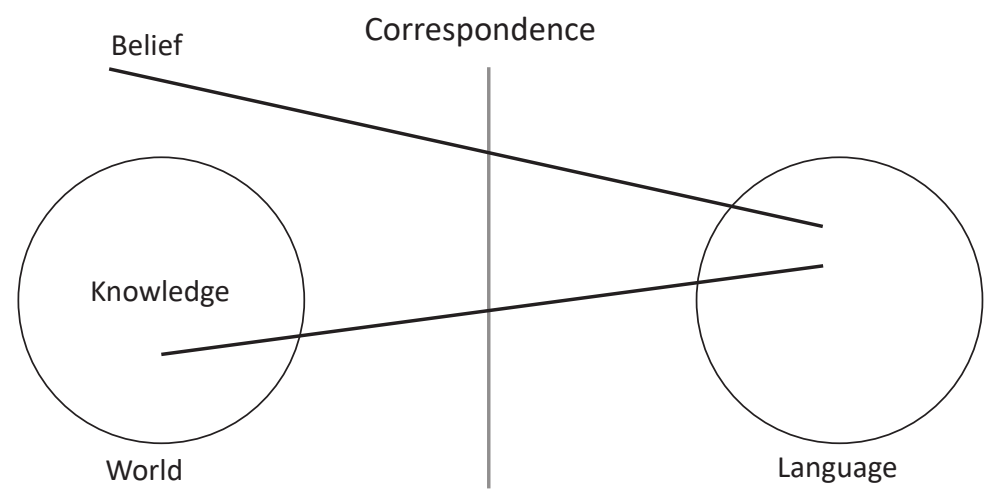

Figure 2. Adapted from (Latour, 1999b). On the one side, we have the world of objects in them. On the other, the world of language and symbols ${ }^{7}$. A sentence is said to be true if it finds correspondence with the world of things in itself and can be called knowledge. A sentence that does not find correspondence in the world of objects itself is only a belief.

6 The concept of society appears in Latour's (1999) narrative of modernity as an attempt by the academy to account for the validity of knowledge without claiming Kant's concept of an a priori judgment. In this sense, Latour points out that the absolute and universal validity of concepts is replaced by the validity gained by social consensus. Lakatos (1978) indicates Polanyi (1946) and Kuhn $(1963,1977,1996)$ as the main advocates of consensualism.

7 As Latour (1999b) points out, this modern view rescues the Platonic notion that the world of Ideas is totally separate from the world of matter. 
Thus, in scientific discourse, an entity proposed by a theory exists if we can find it in nature, just as the phrase "there is a dog in the door" is true if we go to the door and find a dog. In this case, we say that the statement was a "knowledge" about the situation. On the other hand, if we reach the door and find no dogs, we say that we had a "belief", but not a knowledge. In this way, the separation between nature and society allows us to create a new distinction, now between knowledge and belief. Every true statement is explained by the pole of nature, whereas any false statement can only be explained by the pole of society (Latour, 1992). Such a relation connects ontology (metaphysics) and epistemology, an interrelationship omitted by "modern epistemologists", who push metaphysics into the background (Latour, 1999). Putting such a reflection in terms of the post-truth debate, going back to the concept from the Oxford dictionary, the true knowledge would correspond to the natural world, while the post-truth would be identified as belonging only to the social pole (belief). On the basis of this dichotomy, the one who guarantees the absolute distinction between the two of them is the separation of nature and society.

From the ontological-epistemological framework summarized in figures 1 and 2 , it is said that science evolves by increasing the number of true sentences or, at least, by decreasing false statements, as proposed by Popper $(2008)^{8}$. This implies that over time we have been able to form an increasingly clear idea of what this world of thingsin-themselves is, through the correspondence between theory and the natural world. This is done by the constant clearance of the subjective in relation to the objective. From this perspective, it is argued that when the scientist works in their laboratory, they can approach the object, moving away from society. In this way, the scientist identifies what are the subjective and therefore unreliable or false aspects of knowledge (their beliefs, their primary intuitions), managing to purge them. It is through this process of laboratory purification that moderns say that they separate all events into two ontological poles: nature (objective reality) and society (subjective reality). In the end, the scientist becomes a representative of nature, a spokesman for scientific facts, a representation that is totally distinct from political representation, which is full of personal interests and power disputes (Latour, 1993, 2013).

Therefore, such discourse still implies the notion of the scientist as an apolitical professional, disconnected from social and economic questions, cloistered in a lab, close only to what is natural and not to what is social. Good science, in the modern world, must free itself from politics. As Latour $(2013,2016)$ points out, the work of Gaston Bachelard $(1996)^{9}$, perhaps, is an important example of such a worldview. Moreover, at the same time it creates a notion of a nature free of society, such metaphysics allows the notion of a society free from nature. Durkheim's sociology, articulated at the beginning of the twentieth century, is therefore a consequence of modern discourse, since it rightly

8 In order to evaluate the implications of Popper's thinking for Science Education, we suggest the studies by Lang (Lang, 1989, 1996) and Lang and Ostermann (2002).

9 For an overview of Bachelard's intellectual production and its implications for Science Education, we suggest the work of Lopes (1996). 
proposes the possibility of analyzing society as an autonomous field, independent of everything that is biological (and, therefore, natural) (Latour, 2001). Such a worldview, likewise, implies translating the duplication of world history (in the history of nature and history of society) into the history of science: historians begin to speak of an internal history (of contents) and an external history (of social relations) (Latour, 1999b) ${ }^{10}$.

With such a vision, we who belong to the collective that develops modern science become a privileged culture among many others that, for not having a method of purification, put together, at any moment, social and natural elements. While scientists go to the lab to interpret the inscriptions of their equipment and discover facts, autonomous, independent, elements of nature, other communities deal only with their fetishes. That is, they "project their own beliefs and desires in an object without meaning" (Latour, 2017, p. 361). The idols of others, elements of their description of reality, are "nothing but mere empty white screens on which is projected the power of society, domination, whatever" (Latour, 2004b, p. 238). In the very definition of posttruth of the Oxford Dictionary we have this dichotomy recovered: on the one hand the fact, on the other the beliefs and emotional appeals (the fetishes). We see, therefore, that the original rupture (between nature and society), such like biblical sin, is the source of all the ruptures of the discourse of modern science (which are summarized in Figure 3 ).

\begin{tabular}{|l|}
\hline Nature and Society \\
\hline Ontology and Epistemology \\
\hline Epistemology and Politics \\
\hline Matter and Signs \\
\hline Knowledge and Belief \\
\hline $\begin{array}{l}\text { Scientific Representation and } \\
\text { Political Representation }\end{array}$ \\
\hline Within science and outside science \\
\hline "We" and "others" \\
\hline Fact and Fetish \\
\hline Truth and Post-Truth \\
\hline
\end{tabular}

Figure 3. What the scientific discourse broke

The question then raised by Latour is this: Can we trust in the discourse of scientism? Is nature and society apart? Are knowledge and existence orthogonal? Are epistemic practices apolitical and political disputes unaffected by epistemic practices? Is matter irreconcilably distant from signs? Are scientific facts different from fetishes? Is post-truth so different from truth? To answer such questions, we need to shortly abandon the discourse of modern science and look more closely at scientific practice understanding what scientists do and not just what they say they do.

10 For a discussion of the historiography of science, we suggest the work by Videira (2007). For the implications of the historiography of science for Science Education, we suggest the book organized by Peduzzi, Martins e Ferreira (2012) and, especially, for the distinction between internal and external history, the chapter by Oliveira e Silva (2012). 


\section{An expanded framework on science: Persistent contradictions between discourse and practice}

In Cogitamus, Latour (2016) discusses Plutarch's account of the story of the meeting between Archimedes and Hieron, the king of Syracuse. The mythical story is synthesized by Latour in four acts. In the first three, we have the following plot: "Act I: Archimedes goes to Hilo to share his craziest ideas with him. Act II: Hieron proposes to Archimedes the challenge of proving the practical usefulness of his ideas. Act III: Archimedes manages to accomplish such a feat that he defends Syracuse of the Romans by himself" (Latour, 2016, p.23). That is, Archimedes (scientist) seeks the king (politician) to offer his services. The (political) king is mobilized, he is interested in Archimedes (scientist), and challenges him to help in defense against the Romans. Archimedes develops the catapult ("discovering" a principle of nature) and thereby alters the outcome of a war between two peoples (political achievement). In the sequence, in Act 4, Plutarch asserts that Archimedes left nothing written, for he considered "no occupation of mechanics and all art to the necessities of life." (Latour, 2016, p.23). That is, after Plutarch narrates that Archimedes sought a politician to offer his works, he tells the scientist as a being devoid of interests by politics. In this little story, three interesting questions arise for Latour:

How is it possible that a man of the sciences can arouse interest in a prince, since the domains of both are completely alien to each other? How is it possible that these distinguished domains are, however, susceptible to a continuity so perfect that they can become commensurable? Thanks to which third miracle, even though they are perfectly united, are they presented as absolutely incommensurable? (Latour, 2016, p.25)

In this sense, there seems to be something contradictory between scientific practice and what is said about it in terms of political interests. In addition, when Latour investigated the practice of scientists in a laboratory (Latour, \& Woolgar, 1986), he realized that scientists do not deal with objective facts (as they claim to do). On the contrary, as Bachelard had already pointed out, the scientific reality mobilizes equipment and theories; it demands a "phenomenotechnique". Scientists claim to discover facts (truths), but when they interpret the signal of a material characterization apparatus, for example, what they do is project their theoretical knowledge onto the inscription (the data does not speak for itself). Such a notion of projection, however, is close to the definition of a fetish. If the data needs to be interpreted, there are no facts without some dimension of fetish. And so it seems that there is a je ne sais quoi of post-truth in scientific truth. We present, next, some reflections on how the main criticisms of Science, with a capital "S", address this question and, in the next section, we discuss Latour's own interpretation. 


\section{Criticism towards Science "with Capital S": Sociology of Scientists, Strong Programme of Sociology, Semiotic Strand}

There are different criticisms of the view of Science with capital S (what we call a discourse of scientism). In particular, Latour mentions three distinct groups of criticism. Although they all oppose supposed objectivity and scientific neutrality, their metaphysical views differ and contrast from Latour's proposal.

\section{a) Sociology of Scientists}

As Latour and Woolgar (1986) point out, the beginning of the field of Sociology of Science is marked by a "Sociology of Scientists", that is, by an area concerned only with human relations with each other. Therefore, even if such a tendency criticizes the neutrality of science, since it exposes the disputes of power that exist in the scientific community, it adheres to the modernist contract, since it maintains society and nature apart. It is up to the Sociology of Science, in this perspective, to explain only what is "social" (in the Durkheimian sense), leaving the content of science (nature) out of such an explanation. Following the comments of Latour and Woolgar (1997), we can mention, for example, the work on competition among researchers (Bourdieu, 1976; Lemaine, \& Matalon, 1969), on the evolution of disciplines (Lemaine et al. 1976), or on their psychology (Mitroff, 1974).

In this sociological proposal, besides keeping nature free of any political discussion, it sticks to the Durkheinian notion of a reified (macroscopic) social dimension influencing the actions of scientists and laboratories (microscopic scale) - what Latour calls 2D Sociology (Latour et al. 2012). Pierre Bourdieu (1997), for example, defines the notion of field, "the universe in which are inserted the agents and institutions that produce, reproduce or diffuse art, literature or science. This universe is a social world, like others, but obeying more or less specific social laws" (Bourdieu, 1997, p.20) ${ }^{11}$. That is, the field (macro scale) that affects the actions of scientists (micro scale) is defined - in the purely human dimension. Nature does not participate in such a discussion. We argue that the contribution of such a sociological proposal is undeniable for the weakening of the science view with capital S, as it explicits the politicized character of scientific practice. However, it is limited as it does not address "nature", the content of science (Latour et al, 2012).

\section{b) The Strong Programme of Sociology}

The moderns' explanation of knowledge, as we have discussed, is asymmetric, for it recognizes nature as the source of true knowledge (facts), whereas the society as the source of beliefs (fetishes). While the Sociology of Scientists does not interfere in this modernist agreement, circumscribing itself to speak of men among men, the

11 There are, today, proposals for the use of elements of Bourdieu's Sociology of Science in Science Education (Lima, Pinheiro, \& Ostermann, 2012). 
Strong Programme of Sociology (SPS) ${ }^{12}$ attacks the heart of the discourse of scientism. David Bloor (1991) defines its four principles 1) Causality, that is, the SPS must explain knowledge and belief; 2) impartiality, that is, the SPS does not distinguish between rationality and irrationality, truth and falsehood, success or failure; 3) Symmetry, that is, the same causes that explain the truth explain the falsity and 4) Reflexivity, that is, the SPS must explain itself.

In SPS, one no longer seeks a sociology of scientists, but a sociology of scientific knowledge, about which scientists speak. The principle of causality (1) indicates that the PFS seeks, as in Durkheinian sociology, causal explanations, that is, what causes belief and knowledge. And, in this sense, society becomes the source of the explanation of all true or false knowledge. The principles of impartiality (2) and symmetry (3) make the PFS a relativistic proposition as it makes it impossible to distinguish between truth and falsehood. In this sense, the PFS represents another strong attack on Science with a capital S, reducing its contents to a social construction and removing any trace of objectivity. By taking society as the cause of all true or false knowledge, this strand of Sociology of Science can be interpreted as one of the supports of the post-truth scenario as Latour (2004) pointed out.

It should be noted, finally, that SPS is "constructivist for nature, and realistic for society" (Latour, 2013, p. 95) ${ }^{13}$. That is, the explanatory symmetry of the SPS supports an ontological asymmetry - still reifying society as an autonomous pole.

\section{c) Semiotic and Post-Modernity}

The third possibility adopted by the critics was to dissolve the two ontological poles in the discourse: neither nature nor society explains anything. We are, forever, bound to the language games. Latour explains: "Unfortunately, the sad story does not end here. Incredible as it may seem, it is possible to go even further on the wrong path, (...). Yes, we lost the world. Yes, we will forever remain prisoners of language. No, we will never be sure." (Latour, 2017, p. 21). What Latour calls the semiotic strand, or Empire of Signs ${ }^{14}$, thus refers to the theoretical perspectives normally presented in the context of post-structuralism, which reduce reality to its discursive dimension: subject and nature become artifacts of discourse. Different perspectives adhere (under different aspects) to such a view. In addition to Derrida (1997), the main name mentioned by Latour as representative of the semiotic aspect, we can mention works by Eco (1981), Greimas (Greimas, \& Courtés, 1982.), Pêcheux (1997) and Laclau (2014) ${ }^{15}$. According to Mcintyre (2018), by reducing reality to the effects of discourse, postmodernism paved the way for the development of the post-truth. Paul Feyerabend (2010), considered one of the great

12 We can mention the proposal of Bagdonas, Zanetic e Gurgel (2014) as an example of study in Education in Sciences that dialogue with the SPS.

13 Latour's interpretation is contested by David Bloor and his antagonism is public (Bloor, 1999; Latour, 1999a).

14 Probably in reference to the homonymous book of Roland Barther (1982).

15 In Education, the text of Alice Lopes and Elizabeth Macedo (2011) is aligned with this notion. For an overview of the different “post”, we suggest Alice Lopes (2013)'s text. 
thinkers of relativism, in a footnote in the introduction of the second edition of Against the Method, mentions that, faced with the advances of some perspectives, such as that of postmodernism, he came to believe that more emphasis should be placed on reason.

\section{An Alternative Metaphysics: From the Primacy of Ontology to the Primacy of Ecology}

On the one hand, we have the discourse of science and all the dichotomies it creates (Figure 3), on the other, we have the scientific practice and the narratives about it elaborated by the Sociology of Scientists, SPS and Semiotic Strand. How to deal with the clash between such visions? Instead of "taking sides" and deciding what is true, the version of the apolitical scientist or the politicized scientist, the version of facts or fetishes, Latour proposes to take the contradiction itself as an object of study, that is, not to try to solve the contradiction, but, first of all, to understand how this contradiction is possible, what happens so that it can exist. Instead of asking whether the hormones found in a laboratory exist or not, or whether the "good" scientist engages in power relations or not, we must ask how it is possible to produce "things" in the laboratory and then have them as autonomous. How is it possible for science to interfere in politics (and vice versa) and then to think that politics and science are distant domains? To try to understand this, neither using apodictic reasoning, a priori theorizing, nor relying on the scientists" narrative are enough, for they are "privileged informants, but always informants of whom one doubts" (Latour, \& Woolgar, 1997, p.20).

The path that Latour presents is to study science in action, during its development, the one that is being made, with all its controversies. This is what Latour and Woolgar (1997) do in Laboratory Life: The Construction of scientific Facts, inaugurating what is called "Laboratory anthropology", or "Wave Two of STS" (Mody, 2015), marking, together with the development of the ontological discussion that will be presented below (Harman, 2009), the entry of Anthropology into scientific and engineering laboratories. Latour is the pioneer of such a field together with other great names in the Sociology of Science (Knor-Cetina, 1981; Lynch, 1985) ${ }^{16}$. It should be noted that such a movement breaks with the search for a macroscopic sociology of science and starts to worry about specific cases, as in a microsociology of science. It can be understood that this change from a macro look to a micro look also marked historiographical perspectives, as in the case of the Cultural History of Science (Lightman, 2016), for which the study of scientific practices is fundamental for understanding how sciences have formed throughout history ${ }^{17}$. In the case of Science Education, many studies are strongly influenced by Laboratory Anthropology, especially by the seminal work of Latour (Queiroz, \& Almeida, 2004; Rezzadori, \& Oliveria, 2011; Roxael, Diniz, \& Oliveira, 2015; Vianna, \& Carvalho, 2001a). These papers discuss the implications, for science education, of the 16 For an overview of the beginning of the field of Laboratory Anthropology, we suggest the work of Woolgar (1982).

17 There are proposals in Science Education that already discuss the implications of the Cultural History of Science for Science Education (Moura \& Guerra, 2016). 
fact that sciences are much larger than the content they produce.

It is important to emphasize that the ethnographic study is not the only study method used by Latour. On the contrary, one of his most important works, The Pasteurization of France (Latour, 1988b) is a historiographical study in which the writings of Pasteur are analyzed. This work is considered one of the founders of the Actor-Network Theory (Latour, 2005) together with the works of Callon (1984) and Law $(1984)^{18}$.

In making his proposal, Latour does not do so in a discursive void, but stands up by making explicit opposition to all views of Sociology of Science previously presented. In We Have Never Been Modern, Latour comments:

'But then surely you're talking about politics? You're simply reducing scientific truth to mere political interests, and technical efficiency to mere strategical manreuvres?' Here is the second misunderstanding. If the facts do not occupy the simultaneously marginal and sacred place our worship has reserved for them, then it seems that they are immediately reduced to pure local contingency and sterile machinations. (...) “But if you are not talking about things-in-themselves or about humans-among-themselves, then you must be talking just about discourse, representation, language, texts, rhetorics.' This is the third misunderstanding, (...) when I describe the invention-discovery of brain peptides, I am really talking about the peptides themselves, not simply their representation in Professor Guillemin's laboratory. Yet rhetoric, textual strategies, writing, staging, semiotics - all these are really at stake, but in a new form that has a simultaneous impact on the nature of things and on the social context, while it is not reducible to the one or the other. (Latour, 2013, p. 10)

In the transcribed passage, Latour emphasizes that he does not speak of the representation of the peptide (world of language in Figure 2), but actually speaks of the peptides themselves, without letting them leave their rhetorical and social dimensions. That is, for Latour, the reality is natural, but it is not only natural, it is social, but it is not only social, it is discursive, but it is not only discursive. To understand how this is possible within a consistent metaphysical framework, Latour articulates different empirical studies and philosophical discussions around a monadic worldview, which we present in the next section.

\section{Fermentation, Lactic Acid, Pasteur and more Philosophy: how the fabrication of facts makes them autonomous.}

As already mentioned, Latour departs from 2D Sociology to analyze laboratory practices ${ }^{19}$. Its purpose, as we have said, is not to resolve the opposition between discourse and practice, but to understand how the contradiction between them can

18 The Actor-Network Theory (ANT) will be discussed next in the text as well as the research works in Science Education that use it.

19 Latour is criticized by sociologists of science, because, in doing so, he would be losing the social dimension, which only appears on the macro scale (in society and not in the laboratory) (Lorenzi, \& Andrade, 2011; Schinkel, 2007). 
exist so naturally, how it is possible that, although constructed, scientific facts seem so autonomous and independent of any creation. For this, we take the example of Latour analyses on Pasteur (Latour, 1983, 1988b, 1999c, 1999b), whose works showed that the fermentation had biological causes and not purely chemical, as assumed the hegemonic view of the time.

To propose the existence of lactic acid, Pasteur needed the mediation of what Latour calls "laboratory tests". In such tests, a certain sample to be characterized is subjected to an apparatus, such as a microscope, which produces a certain result, an inscription $^{20}$. Such inscription is the result or the performance of the sample + apparatus system. So, at the end of a lab test, all we have is:

\section{Test 1: Sample + Inscriber $_{1} \rightarrow$ Inscription $_{1}$}

We can repeat this procedure $n$ times:

\section{Test 2: Sample (Proposition 2) + Inscriber $_{2} \rightarrow$ Inscription $_{2}$ (...) \\ Test n: Sample (Proposition n) + Inscriber $_{n} \rightarrow$ Inscription $_{n}$}

At the end, we have a set of $n$ inscriptions that refer to sample-subscriber systems. None of this is lactic acid, the fact to be discovered. Pasteur also needs to interpret such inscriptions in the light of prevailing theories, giving it physical meaning. At this moment, the inscriptions (mere semiotic elements) become performances of that system in the real world, that is, they begin to describe how something in the world behaves. For lactic acid to exist, however, one more element is needed: the scientist must associate it with $n$ performances, interpreting that they are jointly consistent with the existence of something new and singular - lactic acid.

Lactic acid, in no time, was accessed directly, but only its performances. Such performances, however, are the result of the articulation of the entire network: the sample, the equipment, and the interpretations given by Pasteur from other theories. They were not ready, given, at the ontological pole of nature, waiting to be unveiled. The term lactic acid becomes the label that hides the network. It cannot exist if Pasteur does not project such label onto the network. The discovery of the fact, in fact, always involves a fetishistic dimension (Latour, 2017). But this does not in any way diminish the validity of what has been articulated. The more well-constructed the fact is in the laboratory, that is, the more extensive and reliable the network articulating a fact, the more "real" it becomes. Likewise, the more well-articulated a fetish is, the better is the effect it has on people in relation to what is expected of it (Latour, 2004b). The similarity between the two words is not coincidental and, frankly, both have the same etymology, facts and fetishes are two sides of the same phenomenon. Hence, Latour suggests abolishing such a dichotomy in favor of a single term, factish (Latour, 2004b, 2017).

20 "General term referring to all kinds of transformations that materialize an entity into a sign, a file, a document, a piece of paper, a line" (Latour, 2017, p. 362). For an analysis of the role of inscriptions in Science Education, we suggest the works of Roth and Tobin (1997) and Oliveira (2010). 
Thus, we cannot think that lactic acid is something of the natural, social, or linguistic world purely, but a hybrid of nature, language, and society. By the way, everything Pasteur went through, at every moment, were hybrids. Even the first selected sample is no longer a purely natural sample, since it was chosen from all possible bodies of the Universe for pre-established reasons, that is, it already means something in the discourse. In the same way, used equipment are not simply matter, since they also participate in a discursive chain, being constructed from theories and allowing the production of performances that also "mean" something ${ }^{21}$.

Suppose now that the apparatus used for test 1 was found to be contaminated, the apparatus of test 2 was uncalibrated, the theory used to interpret test 3 was invalidated by another finding and so on. Gradually, the lactic acid, so real, loses all its existence. What guarantees the existence of lactic acid is not itself (like the objects-in-themselves), but the network that is mobilized for its existence. If the network is disarticulated, lactic acid ceases to exist.

Latour's view can therefore be labeled as non-essentialist. That is, it is not part of the notion that there is an essence in nature about to be discovered (Lima, Ostermann e Cavalcanti, 2018a). Actors ${ }^{22}$ (or actants) are constructed by articulation with other actants. Nature does not have to be understood as a zero-sum game, that is, we do not have to limit ourselves to the poverty of a world of things-in-itself with a finite number of objects to be discovered. The reality is much more complex than that, and the sciences produce much more complex propositions than the statement that a dog is at the door.

Such an ontological view can be explained in terms of Whitehead's Theory of Propositions (1978). Propositions ${ }^{23}$ are not sentences, they are actants (or actors) and their only a priori property is that they exist through the articulation between them (Latour, 1999b). That is, we are dealing with a metaphysics that does not place existence in the being itself and, therefore, breaks with the ontology (as defined in footnote 5). Existence is given by the relations of association with other entities. It is a relational metaphysics, which Latour calls ecology (Latour, 2001).

Thus, for example, the "discovery of lactic acid" involves the articulation of lactic acid by different propositions, such as Pasteur and yeast. Pasteur (human) and yeast (nonhuman) articulate, mobilizing lactic acid (Latour, 1999b). Before this articulation,

21 For further reference on the hybridization between matter and signs, we suggest Chapter 2 of Pandora's Hope (Latour, 2017) and the article The Berlin Key or how to do with things with words (Latour, 2000).

22 "Instead of starting with entities that already make up the world, scientific studies emphasize the complex and controversial nature of what it is, for an actor to come into existence. The key is to define the actor based on what they do - their performances - in the framework of laboratory tests" (Latour, 2017, p. 358). In the case presented, the sample, Pasteur, the equipment and theories are all actants that are articulated generating a new actant, the lactic acid. It is observed that humans and nonhumans are treated symmetrically, all are actants that articulate with other actants, generating performances. In this sense, one can no longer think of a human society among themselves. Non-humans are part of this society. On the other hand, one cannot think of a free nature totally free of social aspects. In addition, Strum and Latour (1987) and Latour (1996) warn that even in "Nature" one can already find what we call social interactions.

23 The term proposition, as well as actant, can be used to describe elements that, in the modern view, are classified as objects of nature, society or discourse. 
there was no lactic acid, after it there. One cannot also think that Pasteur used leaven to articulate lactic acid, as if only the human had participation in the process, since nonhumans resist the human will by modifying the performances of the network (Callon, 1984; Latour, 1988b).

In addition, if it stops being articulated, the lactic acid ceases to exist (Latour, 1999 b). For the fermentation with lactic acid, it is necessary that a whole laboratory network is built. If today we lose all knowledge of laboratory practices we have, it is possible that the thesis of spontaneous emergence would circulate again between us (Latour, 1999b). The number of actors that make up reality, therefore, changes with advancement of scientific practice, which can create new actors and destroy old ones. It is the materiality of such a network, such as the network of laboratories, that guarantees its existence. Nature is not something that has always existed and will always exist. It is as full of historicity as humanity itself. We no longer need to think that nature is something independent, that there is "there", waiting to be discovered. "Nature" is what we articulate.

It is through the articulation of different propositions (inscribers, theories, scientists) that the actant might "be". Its existence depends on the network that articulates it. The more propositions are articulated, the greater will be the existence of such a proposition $^{24}$. And so, we solve the problem of the contradiction between discourse and practice of science - the more articulate the factishes, the more autonomous they become, the freer of human mediation, and therefore the more factual. The more we build a factish, the more like a fact it becomes. So, both scientific practice and discourse are correct. Yes, scientists make truths in the laboratory. But, also, yes, such truths become autonomous.

This brings a direct consequence on the fact and belief dichotomy present in the definition of post-truth. Since there is no longer a natural, objective, isolated world as the source of truth, we cannot differentiate between the fact of belief. However, as propositions exist through articulation with other propositions, we can say that each proposition has a space-time interval or envelope of validity (identified by the network used to articulate that proposition). The more propositions are articulated to a proposition, the greater will be its space-time envelope of validity.

A scientist in a laboratory, for example, wants to claim the existence of a hormone. If he simply does this, the hormone, as a proposition, will not have a space-time envelope of significant validity. If, on the other hand, the scientist is able to produce several inscriptions, making their interpretations in the light of strong and credible theories, the hormone will be a highly articulated proposition and thus with an envelope of much greater validity. The envelope of validity of the articulated actant extends through the network of $n$ tests performed. If more tests are done to articulate the existence of such an actant, the greater its envelope. If, on the other hand, the tests are disarticulated, the

24 Existence is no longer a binary property (either exists or not), but corresponds to a spectrum of possibilities. Existence is a relative property. To exist is to exist for the network. Moreover, nonhumans have the right to have historicity as humans since their essence is also in constant stabilization. 
actant will have its envelope reduced.

A modern would say that the scientist discovered the hormone (a fact) and that it has always been there; Latour would say that the hormone (a factish) was articulated by theories and experiments. The more propositions are used, that is, the more constructed the hormone is, the more "real" it will be. And so, construction is what allows the reality of scientific objects as well as the "veracity" of an affirmation - ontology and epistemology are fused into a single view (Latour, 1999b).

So the difference between what the moderns call fact and fetish (or knowledge and belief, truth and post-truth) is not that one corresponds to the real world and the other does not; both are factishes, but they have different spatiotemporal envelopes. Although this symmetry seems to imply a high degree of relativism, since it reinforces the local and temporary character of every proposition, it allows us to "classify" the propositions (not because some are true and others are false) in terms of their articulation: wellarticulated propositions have greater envelope of space-temporal validity.

We can use an example to understand this: an absolutist epistemologist would say that the flat Earth model is false while the round Earth model is true. Latour sees this example in a more complex way than such a dichotomy. Flat earth is a proposition, and as such, it articulates with other propositions, such as religious texts, and some experiments allied with pre-Newtonian conceptions. Round Earth, in turn, is a proposition and, as such, articulates with other propositions, as empirical data and experiments associated with Newtonian conceptions. The difference between them is evident when we realize that the number of propositions capable of being mobilized by the second model is much larger than the first, therefore the round Earth has an envelope space of validity much greater and more significant than the one of Flat earth. While the claim that the Earth is flat can sustain itself for some meters, the claim that the Earth is round can be articulated in a much larger space. Nevertheless, the notion of a round Earth is also not universal, having a limit of validity, since it is not articulated with earth's form and flatness data, for example.

It should be emphasized that such a network is articulated by humans and nonhumans, depending also on economic and political relations. Thus, Latour describes symmetrically, for example, how Elliot, in developing a nuclear energy program, mobilized the neutrons ("nature") inside the laboratory and the Ministry of Defense ("society") outside the laboratory to achieve its objectives, namely, Latour shows how scientific goals are translated into political objectives and vice versa (Latour, 1999b) in a tangle of complex and diffuse relationships that are not restricted to the space and actors of the laboratory.

To explain these relationships, Latour makes a description of scientific activity using a model of circulatory system. For him, there are 5 processes that form the scientific practice (Latour, 1999b). The first is the mobilization of the world, which involves laboratory practice (understood here as the mobilization of different actants or the articulation of different propositions). The second is autonomization, that is, the 
search for colleagues who work in close problems, which allows the support of a research field. The third is the creation of alliances that allow the financing and development of research. The fourth is the public representation, which tries to take and validate the scientific practice before society. Finally, the fifth link corresponds to the nodes and links between all processes. It is the set of this whole system, which involves actors from the most diverse areas of society, which characterizes the scientific practice, which is represented in figure 2 .

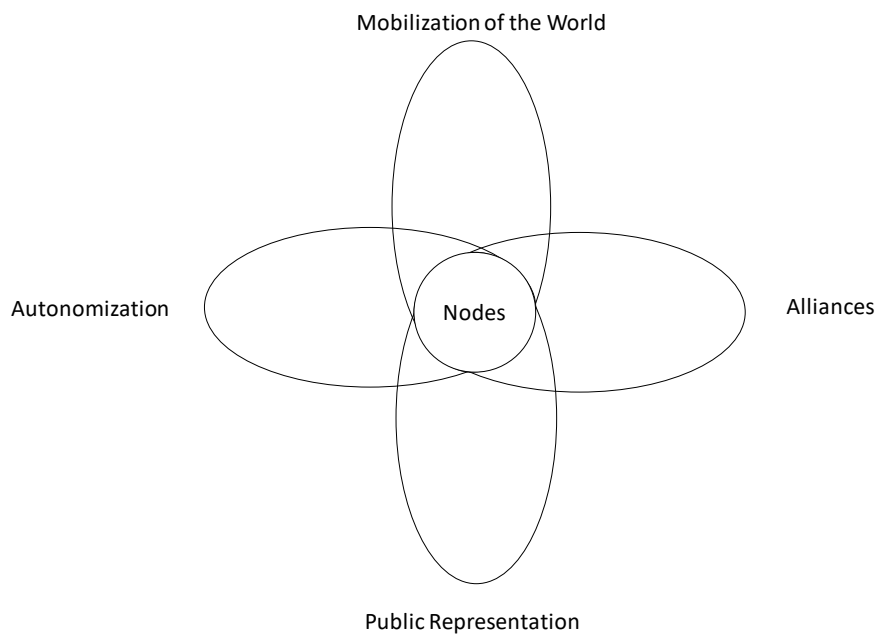

Figure 3. Circulatory System of Science. Adapted from Latour (1999b)

Such a description results, therefore, in another epistemological consequence: there are no interior and exterior of science. When we come close to science in action, we realize that actors from all walks of society are mobilized so that scientific practice can take place. And this solves yet another contradiction presented between discourse and scientific practice. For a fact to be autonomous it needs to mobilize the whole of society, thus it hybridizes with political issues. However, the more "well-done" the political work is, the more articulate and therefore the more autonomous becomes that fact, apparently free from any policies. In order for a fact to "get rid" of its social side, it must first articulate with society. The two views, that of the politicized and nonpoliticized scientist, are consistent though they seem contradictory. The politics and the creation of the facts, therefore, do not diminish the validity of science, they are exactly what guarantees it.

We are finally able to put the post-truth debate in a new perspective, and thus redefine the meaning given by the Oxford dictionary. When a group presents an alternative view to science, we are not dealing with an opposition between truth and falsehood or knowledge and belief or fact and fetish. We are dealing with a competition between propositions. The scientific proposition articulates its network of propositions and that of the alternative group as well. This happens all the time within science itself and is a legitimate process. What we may call post-truth, however, are propositions which, though much less articulated than scientific propositions, are disclosed as 
equipollents or superior to them ${ }^{25}$. In the case of global warming, for example, groups financed by sectors economically interested in the subject support their proposition as if it were equivalent to the results obtained by the whole scientific community, trying to impose a false controversy. Although it does not deal with an absolute truth, from the presented metaphysics, it is possible to decide to adopt measures that diminish the impact of the human action on the greenhouse effect since it is possible to verify that the scientific network has an envelope of greater space-temporal validity (it articulates more propositions) than the antagonistic view.

\section{The Collective: a society of humans and nonhumans}

To conclude the discussion on Latour's metaphysical vision, we point out, for reasons of completeness, that it breaks not only with modern epistemology, but also with modern sociology. Up to this point, we have discussed how Bruno Latour's symmetrical vision calls for a profound revision of concepts about nature, truth, and fact. It should be borne in mind that his symmetrical vision also requires a reformulation of our view of society (Latour, 2013). Some of the criticisms of Latour refer precisely to his break with the hegemonic view of sociology.

By adopting the Theory of Propositions (Latour, 1999b) or the Symmetric Sociology (Latour, 1999b, 2013), nature and society are no longer the ontological poles that serve as a source of explanation. On the contrary, they are what will be constructed and explained in a contingent and temporary way (Latour, 2013). At the end of a scientific process, nature and society will be built, stabilized, and cannot be the source of explanation.

The notion that there is a social reality, a social context and a social force that cannot be reduced to other fields is an a priori assumption of the hegemonic view of modern sociology (as in Durkheim's Sociology) against which Latour opposes (Latour, 2005). Thus, for very different reasons, Latour agrees with Margaret Thatcher's phrase: "There is no such thing as a Society (Latour, 2005, p. 5).

Staying true to his ontological-epistemological view, Latour (2005) proposes a change in the meaning of Sociology, from Science of Society to Tracking Associations. The aim of sociology should be to trace the existing associations between the different actors that make up a network and not seek sociological explanations. It should be noted, however, that unlike Durkheim's sociology, where there are two social scales (the individual and the society), the network is not on a social scale other than the scale of

\footnotetext{
25 We are not arguing that every time an alternative group to science pronounces itself, the most articulate version is that of science. This should be considered on a case-by-case basis. Since in ecological metaphysics there is no distinction between fact and fetish, in each case one must investigate the space-time envelope of validity of a proposition. There are cases in which, possibly, the proposal of the experts may be contradicted by a population since the network is social and technical and therefore, not always the solutions found depend only on epistemic factors. Finally, it should be noted that the validity of one proposition over the other is always spatially contingent (depending on the extent of the network) and variable in time; and the proposition, today, "more real" may be disjointed in the future. Sociotechnical choices, in this sense, are always provisional and must always be under suspicion.
} 
the actor, it is on the same "level", but broken down differently (Latour et al., 2012). This presupposition also means bringing into the sociology all kinds of connections, from chemical bonds to legal constraints (Latour, 2005). In this way, we understand that the collectives of humans and non-humans compose a set of heterogeneous actors that interact with each other. It is this set and its associations that become the object of analysis of this expanded sociology. With this in mind, Latour (Latour, 1988b), Callon (Callon, 1986) and Law (Law, 1986) propose the Actor-Network Theory (ANT), inspired by the sociology of Gabriel Tarde (1999).

Adopting the terminology of Tarde (2007), actors are understood as monads of Leibniz (Latour et al., 2012), that is, the actors do not interact in a network, they are defined by the network (Latour et al., 2012):

Let's say that we have been just told that 'Hervé C.' is now 'professor of economics at Paris School of Management'. At the start of the search it is nothing more than a proper name. Then, we learn that he has a 'PhD from Penn University', 'has written on voting patterns among corporate stake holders', 'has demonstrated a theorem on the irrationality of aggregation', etc.. If we go on through the list of attributes, the definition will expand until paradoxically it will narrow down to a more and more particular instance.Very quickly, just as in the kid game of Q and A, we will zero in on one name and one name only, for the unique solution: 'Hervé C..'Who is this actor? Answer: this network. What was at first a meaningless string of words with no content, a mere dot, now possesses a content, an interior, that is, a network summarized by one now fully specified proper name. The set of attributes - the network - may now be grasped as an envelope - the actor - that encapsulates its contente in one shorthand notation. (Latour et al., 2012, p. 592).

Thus, the Actor-Network Theory proposes a vision of how the actors should be understood. There are no actors and their networks: actors are networks. What is seen as an actor at a certain distance becomes a network as we approach. In this way, the actor is not a fixed, rigid entity, with a pre-existing essence and with autonomous properties; but something temporary, constructed, which demands effort to be stabilized and to continue existing, exactly as Whitehead's propositions. A proposition exists only through articulation with other propositions in the same way that an actor exists only through association with other actors.

In terms of reflection on Science Education ${ }^{26}$, it is important to note that Latour developed a didactic version of ANT, known as Cartography of Controversies (Venturini, 2010), which can be summarized in one single indication: "just observe and describe the controversies" (Venturini, 2010). Far from being associated with the view of unmediated observation, the cartography of the controversies proposes just the opposite:

26 In the research in Science Education, there are several papers that use the ANT as a theoretical-methodological foundation. This perspective allows the investigation of different themes, such as didactic activities (Candela, 2010; Coutinho et al., 2014; Coutinho et al., 2016), scientific projects (Faria, \& Coutinho, 2015), textbooks (Coutinho, \& Silva, 2014), student laboratory (Rezzadori, \& Oliveria, 2011) and "content" (Pierce, 2015; Van Eijck, 2010). Still, there are proposals for the elaboration of didactic units from ANT (Coutinho, \& Silva, 2016). 
Deprived of the protection of concepts and protocols, observation does not get any purer. On the contrary, it opens to all sorts of interferences and impurities. Far from being a clear substance distilled from collective chaos, scientific knowledge is the result of as many contaminations as possible. Such is the lesson of "just": observation devices are the more valuable, the more they let those who are observed interfere with those who observe. (Venturini, 2010, p. 60).

Such a proposal can be further broken down in three directions: (1) do not restrict its observation to a single theory or methodology, (2) observe as many views as possible, and (3) listen to the voices of the actors more than their theoretical assumptions. The complexity and amount of data that a cartography of the controversies or the ANT can demand makes them suitable for exploitation using digital resources (Venturini, 2012; Latour et al., 2012).

\section{Reflections on Metaphysics, Post-Truth and Science Education}

From what has been discussed we are able to explain how the post-truth understood here as propositions that, although much less articulated than the scientific propositions, are disclosed as equipollents or superior to them - gains strength in the face of the visions of the scientific world and of the three criticisms presented to these views. In particular, we will differentiate two distinct mechanisms for this to happen and how Science Education has collaborated for both.

\section{a) Mechanism I: Formation of a limited vision on the Nature of Science in the sphere of public opinion.}

One of the links that constitute the blood flow of science is the public opinion - the view of the members of our society who do not directly participate in scientific practice (Latour, 1999b), i.e. non-specialists whose knowledge of science is obtained, mainly, through the Basic Education. Although there are other forms of scientific dissemination, it is at school that most people receive their knowledge about not only the contents of science, but also (even implicitly) about what science is. In this way, scientific education cannot be thought of as something apart from science, but an element of its own network (Weinstein, 2008). There is no science "there" inside the laboratories, while we, "here", at school, only divulge or transmit it. Scientific education forms public opinion, which, in turn, mediates scientific development.

From this understanding, it can be seen that the notion of science inherited by public opinion through Science Education remains the absolutist view of science as a conservative practice (Lemke, 2011), positivist (Kincheloe, \& Tobin, 2009) , objective and savior of humanity (Deconto, 2014). In doing so, one can imagine that the sciences are being strengthened. We understand, on the contrary, that such a portrait ends up weakening it. This is because, as we have seen, science depends on human mediation, deals with factishes and not facts, involves political disputes and subjective aspects. It is not the supposed Objectivity and Universality (with capital $\mathrm{O}$ and $\mathrm{U}$ ) that are the 
strengths of the sciences, but rather the fact that they articulate extensive networks.

Thus, if public opinion assumes Science as having a capital S, whenever one points the politicized side (Sociology of Scientists), the social influence (SPS) and discursive strategies (Postmodernism), the validity of that knowledge is brought into disrepute. Thus, whenever Science Education portrays science as something only of the natural world, it produces a reduced presentation and ends up weakening science itself, since it will be enough for the interested groups to reveal the political dimension of a certain scientific group in order to diminish their credibility before the public opinion. Proposals for Science Education that align with the three criticisms (we have given some examples throughout the text) also weaken the sciences, since they do not take into account the role of nonhumans in the construction of our society, also presenting a reductionist view ${ }^{27}$. Thus, in synthesis, the first mechanism of the weakening of sciences (which consequently strengthens other visions) is the presentation of a reduced vision about its nature, a practice that has been implemented by traditional Science Education.

\section{b) Mechanism II: Erasure of the network that supports the scientific proposals}

As Latour and Woolgar (1986) point out, something becomes an autonomous "fact" when the network that articulated it is completely erased from scientific texts. "Pasteur's microbes" only become "nature's microbes" when we no longer need to remember all the experiments and theories that Pasteur had to mobilize. This is a natural process: as the actant articulates with the network, it becomes independent. Such autonomy, however, has a side effect when it reaches public opinion, because, although the scientific community has followed the process of stabilization and autonomization of that actant, the population is usually presented to the already stabilized actant. Lima et al. (2018) discuss, for example, how the photon, despite going through more than 80 years of controversy, articulation and disarticulation, is presented by textbooks as an actant of nature, erasing most of the network that articulated it. In this case, the authors of the textbooks use a positivist and authoritative discourse to support their narrative about the photon (Lima, Ostermann, \& Cavalcanti, 2017, Lima et al., 2018b) and only inform students about its existence without explicitly articulating it. This "erasure" of the network by Scientific Education is represented in Figure 5.

27 It does not mean that they are wrong, but they are telling only "a part" of the story. As advocated by the Cartography of Controversies, we should try to approach an actor by as many forms as possible (Latour et al., 2012). 


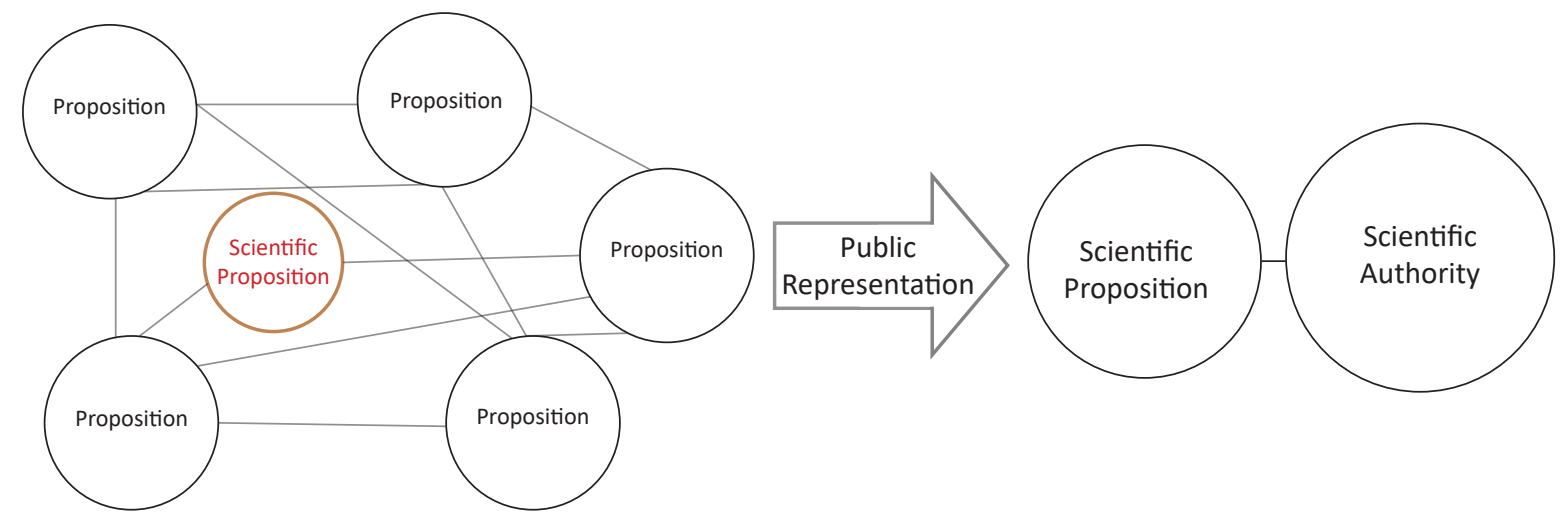

Figure 5. Erasure of the science network by Scientific Education in the process of public representation. The figure is merely illustrative. Imagine that there is an extremely extensive network on the left side of the arrow.

From ecological metaphysics, it is noticeable that, in doing so, science is taken its "true power" - the network that supports its propositions. In stating the scientific propositions as autonomous, we disconnect them from the networks, removing any anchor of reality. The writing of textbooks is inspired by a modern worldview, which takes the pole of nature as the source of truth (metaphysics of Ontology); obscuring, therefore, that the guarantee of the validity of a proposition is given by its network, which is explained by the metaphysics of ecology.

Thus, textbooks, on the one hand, emphasize the false neutrality and objectivity of science (what is not its strong point) and, on the other hand, do not trace the networks that support actants (what guarantees the validity of science). The danger of such a practice becomes real when alternative groups, which articulate propositions in less extensive networks, following the same path, present their proposal to public opinion without tracing the networks that sustain it and thus place it as equipollent to the scientific version, which we represent in Figure 6.

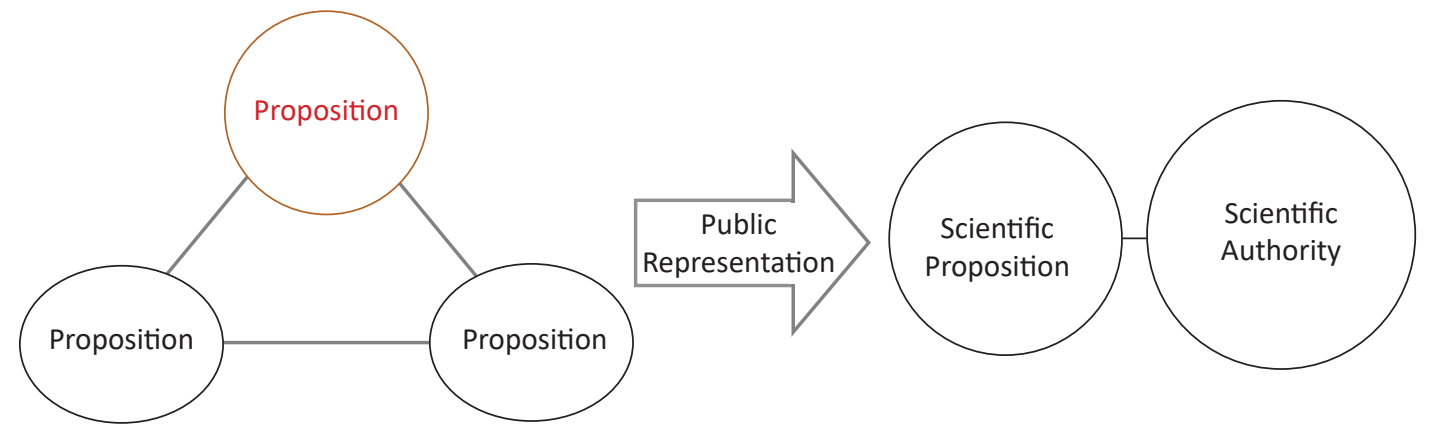

Figure 6. Less articulated proposal, little accepted by the scientific community, being presented to public opinion as equipollent to the scientific version.

Public opinion has received from Science Education only the right side of the arrow in Figure 5. When alternative groups present their version, they do so through 
the right side of the arrow in Figure 6. For example, it can be seen that in the news about quantum healing, usually anyone who speaks up is presented as a researcher, $\mathrm{PhD}$, member of some important university in Europe or the United States. Thus, for the lay population, the proposition represented in Figure 6 is similar to that of Figure 5. By omitting the mediation of humans and nonhumans in the articulation of the network in Science Education, we prevent society from appreciating the difficult work of the sciences, their unofficial work, the articulation of networks. This way allows any proposition to be presented as a scientific truth, and public opinion then has difficulty distinguishing the various propositions.

In the case of the flat Earth, an example given in this article, it can be noted that students or people outside the academic world, when asked about the shape of the Earth, usually respond "round". When asked how they know this, they respond "because I have learned this way". That is, similar to what Lima et al. (2018) point out regarding photons, as people are informed that the Earth is round, but they do not know how such a proposition is articulated.

\section{Science Education sustained by an Ecological metaphysics}

There are already different and important contributions to Science Education from the legacy of Bruno Latour. Beginning with the recommendation of the first articles published in Brazil about the French philosopher (Vianna, \& Carvalho, 2001b, 2001a) to extrapolate the teaching of scientific content, bringing the student closer to scientific practice. This proposal is also found in the international literature (Mody, 2015). Putting it in terms of what has been discussed, this means not reducing the Nature of Science to the discourse that is made about it, explaining the practices that are carried out by the unofficial science. In addition, Mody (2015) recommends the adoption of scientific practices in Science Education such as privileging the writing and reading of scientific texts, and Massoni and Moreira (2017) indicate the need to bring contemporary science into the classroom. In addition, it is possible to find the proposal of bringing the aspect of social construction of knowledge to the didactic discussions (Richard, \& Bader, 2010) and proposal of elaboration of didactic sequences from an actor-network conception (Coutinho, \& Silva, 2016).

What we want to propose in this work, however, is something simpler, though that does not mean it is easier. The only suggestion we intend to make is to change the metaphysical basis in the discourse on science, abandoning the modernist contract that separates nature and society. With this, we propose the abandonment of the primacy of ontology, in favor of the primacy of ecology. To do so means recognizing that what sustains the reality of a scientific proposition is the network it articulates. Thus, instead of informing about the existence of an actant and, from this, instrumentalizing students to solve problems and lists of exercises or make them decorate information about such actant, we propose that the focus of teaching is to highlight the network that supports such a proposition and the socio-scientific controversies that led to or lead to its articulation. 
That is, trying to show how it was possible for that proposition to come into existence.

There is no obvious or trivial way to do this, and didactic proposals that adopt such a vision can range from a more "timid" strategy to the adoption of the Cartography of Controversies and Actor-Network Theory as has been done in the literature (Coutinho, \& Silva, 2016; Faria, \& Coutinho, 2015). The adoption of such proposals varies depending, first, on the teacher's interest, the flexibility of the curriculum adopted and the time available for teachers and students to engage in such activity.

Therefore, our goal is not to make recommendations; but to raise possible glances on how to engage in science education in post-truth times. Thus, for example, instead of adopting an instrumentalist or informative approach, such as textbooks, we can look for an articulatory didactic strategy. That is, instead of simply teaching that the Earth is round or that vaccines work, one can discuss what evidence supports such ideas (by denaturalizing the notion that one is faced with an autonomous and obvious fact, but a proposition which is articulated with a data network, experiments, theories, equipment and scientists) and how this network tries to be disarticulated by competing programs and vice versa. In this context, we can also discuss the issues of power and dispute that involve scientific practice. Using the Latourian terms, this is equivalent to opening the black box of science (Latour, 1988a).

By adopting such measures, we are helping to resolve the two post-truth creation mechanisms explained earlier. By tying the actors in their networks, we gradually show that what strengthens a scientific proposition is the network it articulates, not a supposed objectivity. Thus, when alternative proposals present themselves to public opinion, they will have to mobilize a satisfactory network to deal with what has already been autonomized by science. By explaining the political and social disputes that exist within science as something normal to scientific practice and that it does not hurt its "quality" - we gradually change the concept of science that public opinion can have; reducing the chance that research will be diminished by attributes that are indispensable for its support. This does not guarantee, of course, that post-truths will be abandoned; but simply contributes to the formation of citizens who are more likely to develop a reflective look at the knowledge presented to them. Besides, how far the teacher wants and can go inside of Pandora's Box depends on their work context and must be deliberated by themselves. The basic goal, however, is simply to retake the actors in their networks, ensuring the materiality of their existence.

\section{Final Considerations}

In this work, we proposed a reflection on the formation of post-truths and the role of Science Education in such a scenario. Starting from the definition given by the Oxford dictionary in 2016, when post-truth was chosen as word of the year, we brought metaphysical reflections about modern science and its main criticisms (the Sociology of Scientists, the Strong Programme of Sociology (SPS) and Postmodernism) according to Science Studies of Bruno Latour (1983, 1988a, 1993, 2001, 2004b, 2005, 2016, 2017; 
Latour et al., 2012). We also presented an alternative metaphysical view developed by Latour and collaborators in their ethnographic and historiographic studies in dialogue with Gabriel Tarde's Monadologic Sociology (Tarde, 2007), Michel Callon's Symmetrical Sociology (1984) and the Philosophy of Propositions by Alfred Whitehead (1978).

From this other metaphysics, which Latour (2001) calls Ecology, one can redefine the concept of post-truth; not being the confrontation of a knowledge with a belief (or fact versus fetish); but the confrontation of two propositions that, despite articulating networks of different extensions, are presented to public opinion as equipollents. We have proposed two mechanisms that are used to weaken scientific propositions, leading to the conclusion that scientific education with absolutist epistemological bias weakens science itself rather than strengthens it, as one might think in principle. In this way, we argue that both absolutist views and relativistic views contributed to the post-truth scenario.

The proposal that we make, in dialogue with the research studies in Science Education that already bring a deep reflection on the work of Latour (Candela, 2010; Coutinho et al., 2014; Coutinho et al., 2016; Coutinho, \& Silva, 2014, 2016; Massoni, \& Moreira, 2017; Mody, 2015; M. A. Oliveira, 2010; Queiroz, \& Almeida, 2004; Rezzadori, \& Oliveria, 2011; Richard, \& Bader, 2010; Roth, \& Tobin, 1997; Roxael et al., 2015; Vianna, \& Carvalho, 2001a, 2001b; Weinstein, 2008), is an investment in a metaphysical turn. We do not want to make a "Latourian proposal" of teaching. We suggest only that, by recognizing that the network that articulates a proposition guarantees its existence, education should make explicit such networks, connecting the propositions with the sociotechnical materiality that underpins it. In doing so, we will be contributing to the formation of a science conception closer to its own practice, weakening the two mechanisms of post-truth formation.

In this period when human action is increasingly entangled with that of nonhumans, what some have called the Anthropocene (Arènes et al., 2018; Latour, 2014; Latour, \& Lenton, 2018), to think about the relations between science, society, and technology is not a question of purely intellectual interest, something to be done in the nooks of humanities faculties. The "nature" is an actor on which decisions are made in the political and public spheres and, in this scenario, the experts come to play a relevant role. The right balance to be sought is the possibility of dialoguing with such scientists, without having to be subservient to an absolutist discourse, nor to fall back on a relativistic view. The right balance is to bring science to democracy (Latour, 2004a). In order for this to be done profitably and safely, there must be a maturation on the part of public opinion not only about scientific knowledge, but about the very Nature of Science, and Science Education plays a crucial role in this process. How to do this? We leave an indication of Latour himself: "Now, scientists have to win back respect. But the solution is the same: You need to present science as science in action. I agree that's risky, because we make the uncertainties and controversies explicit." (Vrieze, 2017). Far from wishing to conclude the question, we hope that the present paper will contribute to the 
debate on the subject and to the maturation of our political responsibility as educators and researchers in Science Education.

\section{Acknowledgements}

The third and fifth author thank the National Research Council (CNPq) for the support offered.

\section{References}

Alvim, M. (2017). Quem são e o que pensam os brasileiros que acreditam que a Terra é plana. Retrieved from https://www.bbc.com/portuguese/brasil-41261724

Arènes, A., Latour, B., \& Gaillardet, J. (2018). Giving depth to the surface: An exercise in the Gaia-graphy of critical zones. The Anthropocene Review, 5(2),120-135

Auler, D., \& Delizoicov, D. (2001). Alfabetização científico-tecnológica pra quê? Ensaio - Pesquisa Em Educação Em Ciências, 3(1), 122-134.

Bachelard, G. (1996). A Formação do Espírito Científico. Rio de Janeiro: Contraponto.

Bagdonas, A., Zanetic, J., \& Gurgel, I. (2014). Controvérsias sobre a natureza da ciência como enfoque curricular para o ensino da física: o ensino de história da cosmologia por meio de um jogo didático. Revista Brasileira de História Da Ciência, 7(2), 242-260.

Barthes, R. (1982). Empire of Signs. New York: The Noonday Press.

Bloor, D. (1991). Knowledge and Social Imagery. Chicago: The University of Chicago Press.

Bloor, D. (1999). Anti-Latour. Studies History and Philosophy of Science, 30(1), 81-112.

Bourdieu, P. (1976). Le Champ Scientifique. Actes de La Recherche En Sciences Sociales, 2(2-3), 88-104.

Bourdieu, P. (1997). Os usos sociais da ciência. São Paulo: Editora UNESP.

Callon, M. (1984). Some elements of a sociology of translation: domestication of the scallops and the fishermen of St Brieuc Bay. The Sociological Review, 32, 196-233.

Candela, A. (2010). Time and Space: undergraduate Mexican physics in motion. Cultural Studies of Science Education, 5(3), 701-727.

Carson, R. (1994). Silent Spring. Robbisdale: Fawcett Publications.

Corrêa, A. (2014). Movimento antivacina gera surto de doenças nos EUA. Retrieved from https://www.bbc.com/portuguese/noticias/2014/02/140221_vacinas_doencas_dg

Coutinho, F. A., Goulart, M. I. M., Munford, D., \& Ribeiro, N. A. (2014). Seguindo uma lupa em uma aula de ciências para a educação infantil. Investigações Em Ensino de Ciências, 19(2), 381-402. 
Coutinho, F. A., Santos, V. M. D. F., Amaral, A. C. R., Santos, M. I., Silva, F. A. R., \& Silva, A. D. J. (2016). Quando os educandos transformam uma sequência didática em um ator-rede: movimentos de translação entre ciência, tecnologia, sociedade e ambiente na educação de jovens e adultos. Experiências Em Ensino de Ciências, 11(3), 178-193.

Coutinho, F. A., \& Silva, F. A. R. (2014). Análise de texto de um livro diático de biologia orientada pela teoria ator-rede: um estudo sobre o tema evolução biológica. Investigações Em Ensino de Ciências, 19(3), 531-539.

Coutinho, F. A., \& Silva, F. A. R. (2016). Sequências didáticas: propostas, discussões e reflexões teórico-metodológicas. Belo Horizonte: FAE/UFMG.

Dahmen, S. (2006). Einstein e a Filosofia. Revista Brasileira de Ensino de Física, 28(1), $3-7$.

Deconto, D. C. S. (2014). A perspectiva ciência, tecnologia e sociedade na disciplina de metodologia do ensino de física: um estudo na formação de professores à luz do referencial sociocultural. Universidade Federal do Rio Grande do Sul.

Derrida, J. (1997). Of Grammatology (Vol. 87). Baltimore: The John Hopkins University Press.

Eco, U. (1981). Lector in fabula. La cooperación interpretativa en el texto narrativo. Barcelona: Editorial Lumen.

Einstein, A. (2006). Física e Realidade. Revista Brasileira de Ensino de Física, 28(1), 9-22.

Fabricius, W. V. (1983). Piaget's theory of knowledge: Its philosophical context. Human Development, 26(6), 325-334. https://doi.org/10.1159/000272894

Faria, S. E., \& Coutinho, A. F. (2015). Educação Científica em ação: a cartografia das controvérsias como prática de cidadania técnico-científica. Caderno de Pesquisa, 22(3), $133-147$.

Feyerabend, P. (2010). Adeus à Razão. São Paulo: Editora UNESP.

Goldstein, R. (2008). Incompletude: A prova e o paradoxo de Kurt Gödel. São Paulo: Companhia das Letras.

Greimas, A. J., \& Courtés, J. (1982). Semiotics and Language. Bloomington: Indiana University Press.

Harman, G. (2009). Prince of Networks: Bruno Latour and Metaphysics. Melbourne: re.press.

Idoeta, P. A. (2018). Por que nem sempre adianta apresentar fatos contra notícias falsas. Retrieved from https://www.bbc.com/portuguese/brasil-44686833

Junges, A., \& Massoni, N. T. (2018). O Consenso Científico sobre Aquecimento Global Antropogênico: Considerações Históricas e Epistemológicas e Reflexões para o Ensino dessa Temática. Revista Brasileira de Pesquisa Em Educação Em Ciências, 18(2),455-491. 
Kant, I. (2005). Crítica da Razão Pura. São Paulo: Martin Claret.

Kant, I. (2009). An Answer to the question: 'what is enlightment?”. London: Penguin.

Kincheloe, J. L., \& Tobin, K. (2009). The much exaggerated death of positivism. Cultural Studies of Science Education, 4(3), 513-528.

Knor-Cetina, K. (1981). The manufacture of knowledge: an essay on the constructivist and contextual nature of science. In Science Observed: perspectives on the study of science. London: Sage.

Kuhn, T. (1963). The function of dogma in Scientific Research. In A. C. Crombie (Ed.), Scientific Change (pp. 347-369). London: Heinemann.

Kuhn, T. (1977). The Essential Tension: Selected Studies in Scientific Tradition and Change. Chicago: Chicago University Press.

Kuhn, T. (1996). The structure of Scientific Revolutions (Terceira). Chicago: The University of Chicago Press.

Laclau, E. (2014). The Rhetorical Foundations of Society. New York: Verso.

Lakatos, I. (1978). The Methodology of Scientific Research programmes(Vol. 1). Cambridge: Cambridge University Press.

Lang, F. (1989). A Filosofia de Karl Popper e suas Implicações no Ensino de Ciência. Caderno Catarinense de Ensino de Física, 6(2), 148-162.

Lang, F. (1996). A Filosofia da Ciência de Karl Popper: o Racionalismo Crítico. Caderno Catarinense de Ensino de Física, 5(2), 9-28.

Lang, F. (2002). A Teoria Do Conhecimento De Kant: O Idealismo Transcendental. Caderno Brasileiro de Ensino de Física, 28-51.

Lang, F., \& Ostermann, F. (2002). A Insustentabilidade da Proposta Indutivista de "Descobrir a Lei a partir de Resultados Experimentais." Caderno Catarinense de Ensino de Física, 19(número especial), 7-27.

Latour, B. (1983). Give me a laboratory and I will raise the world. In K. Knorr-Cetin \& M. Mulkay (Eds.), Science Observed: perspectives on the study of science (pp. 141-169). Bervely Hills: Sage.

Latour, B. (1988a). Science in Action: How to follow scientists and engineers through society. Cambridge: Harvard University Press.

Latour, B. (1988b). The Pasteurization of France. Massachussets: Harvard University Press.

Latour, B. (1992). One more turn after the social turn. In E. McMullin (Ed.), The Social Dimensions of Science (pp. 272-292). Notre Dame: Notre Dame University Press.

Latour, B. (1993). We have never been modern. Cambridge: Harvard University Press. 
Latour, B. (1996). On Interobjectivity. Mind, Culture, and Activity, 3(4), 228-245.

Latour, B. (1999a). For David Bloor... and Beyond: A Reply to David Bloor's "Anti-Latour." Studies History and Philosophy of Science, 30(1), 113-129.

Latour, B. (1999b). Pandora's Hope: Essays on the reality of Science Studies. Cambridge: Harvard University Press.

Latour, B. (1999c). Pasteur on lactic acid yeast: a partial semiotic analysis. Configurations, 1(1), 129-146.

Latour, B. (2000). Berlin key or how to do words with things. In P. M. Graves-Brown (Ed.), Matter, Materiality and culture (pp. 10-21). London: Routledge.

Latour, B. (2001). Gabriel Tarde and the End of Sociocultural. In P. Joyce (Ed.), The Social in Question. New Bearings in History and the Social Sciences (pp. 117-132). London: Routledge.

Latour, B. (2004a). Politics of Nature: How to bring Science into Democracy. Cambridge: Harvard University Press.

Latour, B. (2004b). Why Has Critique Run out of Steam? From Matters of Fact to Matters of Concern. Critical Inquiry, 30(2), 225-248.

Latour, B. (2005). Reassembling the Social: An Introduction to Actor Network Theory. Oxford: Oxford University Press.

Latour, B. (2013). Jamais Fomos Modernos. São Paulo: Editora 34.

Latour, B. (2014). Para distinguir amigos e inimigos no tempo do Antropoceno. Revista de Antropologia, 57(1), 11-31.

Latour, B. (2016). Cogitamus: Seis Cartas sobre as Humanidades Científicas. São Paulo: Editora 34.

Latour, B. (2017). A Esperança de Pandora. São Paulo: Editora da UNESP.

Latour, B., Jensen, P., Venturini, T., Grauwin, S., \& Boullier, D. (2012). “The whole is always smaller than its parts" - a digital test of Gabriel Tardes' monads. British Journal of Sociology, 63(4), 590-615.

Latour, B., \& Lenton, T. M. (2018). Extending the domain of freedom, or why Gaia is so hard to understand. Critical Inquiry, no prelo.

Latour, B., \& Woolgar, S. (1986). Laboratory Life: The construction of scientific facts. Princeton: Princeton University Press.

Latour, B., \& Woolgar, S. (1997). A vida de laboratório: a produção dos fatos científicos. Rio de Janeiro: Relume Dumará.

Law, J. (1984). On the methods of long-distance control: Vessels, navigation and the Portuguese route to India. Sociological Review, 32(S1), 234-263. 
Lemaine, G., Macleod, R., Mulkay, M., \& Weingart, P. (1976). Perspectives on the emergence ofscientific disciplines. La Haye: Mouton/Aldine.

Lemaine, G., \& Matalon, B. (1969). La lutte pour da vie dans la cite scientifique. Revue Française de Sociologie, (10), 139-165.

Lemke, J. (2011). The secret identity of science education: masculine and politically conservative?, 287-292.

Lightman, B. (2016). A Companion to the History of Science. Oxford: John Willey and Sons.

Lima Junior, P., Pinheiro, N., \& Ostermann, F. (2012). Bourdieu en la educación científica: consecuencias para la enseñanza y la investigación. Didáctica de Las Ciencias Experimentales y Sociales, (26), 145-160.

Lima, N. W., \& Nascimento, M. M. (2018). Terapias integrativas: uma disputa epistemológica e política. In XVII Encontro de Pesquisa em Ensino de Física (pp. 1-8). Campos do Jordão.

Lima, N. W., Ostermann, F., \& Cavalcanti, C. J. de H. (2017). Física Quântica no ensino médio: uma análise bakhtiniana de enunciados em livros didáticos de Física aprovados no PNLDEM 2015. Caderno Brasileiro de Ensino de Física, 435-459.

Lima, N. W., Ostermann, F., \& Cavalcanti, C. J. de H. (2018a). A não-modernidade de Bruno Latour e suas implicações para a Educação em Ciências. Caderno Brasileiro de Ensino de Física, 35(2), 367-388.

Lima, N. W., Souza, B. B. De, Cavalcanti, C. J. de H., \& Ostermann, F. (2018b). Um Estudo Metalinguístico sobre as Interpretações do Fóton nos Livros Didáticos de Física Aprovados no PNLDEM 2015: Elementos para uma Sociologia Simétrica da Educação em Ciências. Revista Brasileira de Pesquisa Em Educação Em Ciências, 18(1), 331-364.

Lopes, A. C. (2013). Teorias Pós-Críticas, política e currículo. Educação, Sociedade e Culturas, 39, 7-23.

Lopes, A. C., \& Macedo, E. (2011). Teorias de Currículo. São Paulo: Cortez.

Lopes, A. R. C. (1996). Bacehlard: O Filósofo da Desilusão. Cader, 13(3), 248-273.

Lorenzi, B. R., \& Andrade, T. N. de. (2011). Latour e Bourdieu: rediscutindo as controvérsias. Teoria \& Pesquisa: Revista de Ciência Política, 20(2), 107-121.

Lynch, M. (1985). Art and Artifact in the laboratory science: a study of shopwork and shoptalk in a research laboratory. London: Routledge.

Martins, R. de A., Silva, C. C., Martins, R. de A., \& Silva, C. C. (2015). As pesquisas de Newton sobre a luz: Uma visão histórica. Revista Brasileira de Ensino de Física, 37(4), 4202-1-4202-4232. 
Massoni, N. T., \& Moreira, M. A. (2017). A Visão Etnográfica De Bruno Latour Da Ciência Moderna E a Antropologia. Revista Brasileira de Ensino Ciência e Tecnologia, 10(3), 61-80.

Mcintyre, L. (2018). Post-Truth. Cambridge: MIT Press.

Mitroff. (1974). The subjective side of Science. New York: Elsevier.

Mody, C. C. M. (2015). Scientific Practice and Science Education. Science Education, 99(6), 1026-1032.

Moura, C. B. de, \& Guerra, A. (2016). Cultural History of Science: A Possible Path for Discussing Scientific Practices in Science Teaching? Revista Brasileira de Pesquisa Em Educação Em Ciências, 16(3), 749-771.

Oliveira, M. A. (2010). Alfabetização Científica no Clube de Ciências do Ensino Fundamental: Uma Questão de Inscrição. Revista Ensaio, 12(02), 11-26.

Oliveira, R. A., \& Silva, A. P. B. (2012). História da Ciência e Ensino de Física. In História da Ciência e Ensino de Física (pp. 41-64). Natal: Editora da UFRN.

Otte, M. (1998). Limits of constructivism: Kant, Piaget and Peirce. Science and Education. 7(5), 425-50.

Oxford Dictionary. (2016). Oxford Dictionary 2016 word of the year. Retrieved from https://en.oxforddictionaries.com/word-of-the-year/word-of-the-year-2016

Pêcheux, M. (1997). Semântica e discurso: uma crítica à afirmacao do óbvio. Campinas: Editora da UNICAMP.

Peduzzi, L. O. Q., Martins, A. F. P., \& Ferreira, J. M. H. (2012). Temas de História e Filosofia da Ciência no Ensino. Natal: Editora da UFRN.

Pessoa Jr., O. (2009). A Classificação das Diferentes Posições em Filosofia da Ciência. Cognitio-Estudos: Revista Eletrônica de Filosofia. 6(1), 54-60.

Pierce, C. (2015). Learning about a fish from ANT: acotr network theory and science education in the postgenomic era. Cultural Studies of Science Education, 10, 83-107.

Polanyi, M. (1946). Science, faith and society. London: Oxford University Press.

Ponczek, R. L. (2000). A polêmica entre Leibniz e os cartesianos: MV ou MV2? Cad. Cat. Ens. Fis., 17(3), 336-347.

Popper, K. (2008). Conjecturas e Refutações. Brasilia: Editora Universidade de Brasília.

Porto, C. M., \& Porto, M. B. D. S. M. (2009). Galileu, Descartes e a elaboração do princípio da inércia. Revista Brasileira de Ensino de Física, 31(4), 46011-460110.

Queiroz, S. L., \& Almeida, M. J. P. M. (2004). Do fazer ao compreender ciências: reflexões sobre o aprendizado de alunos de iniciação científica em química. Ciência \& Educação, $10,41-53$. 
Rezzadori, C. B. D. B., \& Oliveria, M. A. (2011). A Rede Sociotécnica de um Laboratório de Química do Ensino Médio. Experiências Em Ensino de Ciências, 6(3), 16-37.

Richard, V., \& Bader, B. (2010). Re-presenting the social construction of science in light of the propositions of Bruno Latour: For a renewal of the school conception of science in secondary schools. Science Education, 94(4), 743-759.

Roth, W. M., \& Tobin, K. (1997). Cascades of inscriptions and the representation of nature: how numbers, tables, graphs and money come to re-present a rolling ball. International Journal of Science Education, 19(9), 1075-1091.

Roxael, F. R., Diniz, N. D. P., \& Oliveira, J. R. S. D. (2015). O Trabalho do Cientista nos Cartuns de Sidney HArris: Um Estudo sob a Perspectiva da Sociologia da Ciência. Química Nova Na Escola, 37(número especial), 68-81.

Santos, B. de S., \& Meneses, M. P. (2009). Epistemologias do Sul. Coimbra: Edições Almedina SA.

Schinkel, W. (2007). Sociological discourse of the relational: The cases of Bourdieu \& Latour. Sociological Review, 55(4), 707-729.

Searle, J. R. (2004). Mind: A Brief Introduction. Oxford: Oxford University Press.

Slezak, P. (1994). Sociology of Scientific Knowledge and Science Education part 2: Laboratory Life Under Microscope. Science \& Education, 3, 329-355.

Strum, S., \& Latour, B. (1987). The meaning of social: From Baboons to Humans. Social Science Information, 26(4), 783-802.

Tarde, G. (2007). Monadologia e Sociologia - e outros ensaios. São Paulo: Cosac Naify.

Valadares, J. (2011). A teoria da aprendizagem significativa como teoria construtivista. Aprendizagem Significativa Em Revista, 1(1), 36-57.

Van Eijck, M. (2010). Addressing the Dynamics of Science in Curricular Refeorm for Scientific Literacy: The Case of Genomics. International Journal of Science Education, 32(18), 2429-2449.

Venturini, T. (2010). Diving in magma: how to explore controversies with actor-network theory. Public Understanding of Science, 19(3), 258-273.

Venturini, T. (2012). Building on faults: How to represent controversies with digital methods. Public Understanding of Science, 21(7), 796-812.

Vianna, D. M., \& Carvalho, A. M.P. (2001a). Bruno Latour e contribuições da antropologia da Ciência: Aspectos para o Ensino de Ciências. Ciência e Ensino, 10, 14-19.

Vianna, D. M., \& Carvalho, A. M. P. (2001b). Do fazer ao ensinar ciências: a import Ância dos episódios de pesquisa na formação de professores. Investigações Em Ensino de Ciências, 6(1), 111-132.

Videira, A. A. P. (2007). Historiografia e história da ciência. Escritos, 1(1), 111-158. 
Vrieze, J. (2017). Bruno Latour, a veteran of the 'science wars', has a new mission. Science. Retrieved from http://www.sciencemag.org/news/2017/10/latour-qa

Weinstein, M. (2008). Finding Science in the school body: Reflections on transgressing the boundaries of science education and the social studies of science. Science Education, 92(3), 389-403.

Whitehead, A. N. (1978). Process and Reality: An Essay in Cosmology. New York: The Free Press.

Wittgenstein, L. (1968). Tratactus Logico-Philosophicus. São Paulo: Companhia Editora Nacional.

Woolgar, S. (1982). Laboratory Studies: a comment on the state of the art. Social Studies of Science, 12, 481-498. 
Nathan Willig Lima

${ }^{\oplus}$ https://orcid.org/0000-0002-0566-3968

Universidade Federal do Rio Grande do Sul (UFRGS)

Porto Alegre, RS, Brazil

Centro Federal de Educação Tecnológica Celso Suckow da Fonseca (CEFET/RJ)

Rio de Janeiro, RJ, Brasil

lima.nathan@gmail.com

Pedro Antônio Viana Vazata

${ }^{\circ}$ https://orcid.org/0000-0001-8780-5343

Universidade Federal do Rio Grande do Sul (UFRGS)

Porto Alegre, RS, Brazil

pedrospring@hotmail.com

Fernanda Ostermann

๑https://orcid.org/0000-0002-0594-2174 Universidade Federal do Rio Grande do Sul (UFRGS) Porto Alegre, RS, Brazil fernanda.ostermann@ufrgs.br

Claudio José de Holanda Cavalcanti

${ }^{-}$https://orcid.org/0000-0002-2477-3150 Universidade Federal do Rio Grande do Sul (UFRGS) Porto Alegre, RS, Brazil claudio.cavalcanti@ufrgs.br

Andreia Guerra

${ }^{\oplus}$ https://orcid.org/0000-0002-6397-3817

Centro Federal de Educação Tecnológica Celso Suckow da Fonseca (CEFET/RJ)

Rio de Janeiro, RJ, Brazil andreia.guerra96@gmail.com

Submitted on 22nd September 2018 Accepted on 23rd January 2019 Published on 05th May 2019 